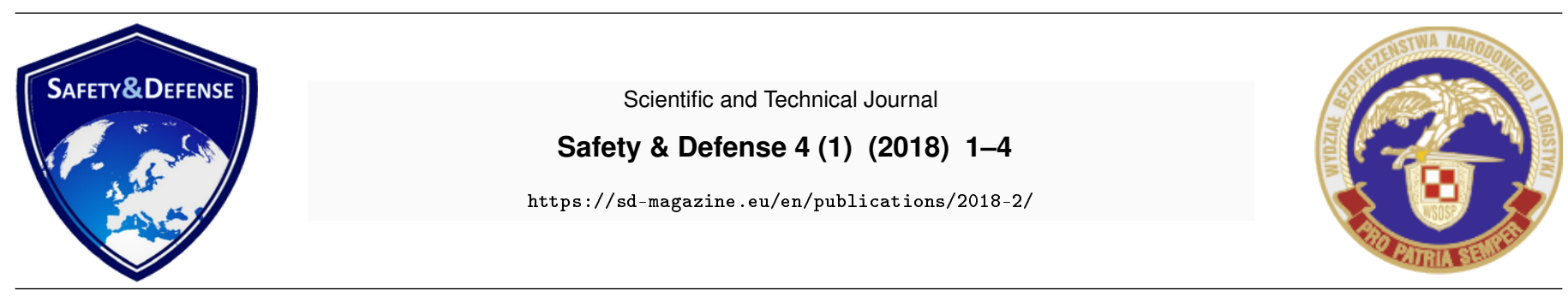

\title{
Activating Methods of Command in the Army
}

\author{
Adam Rurak* \\ National Security and Logistics Faculty, Polish Air Force Academy, ul. Dywizjonu 303 nr 35, 08-521 Dęblin, Poland
}

\begin{abstract}
The article presents inspirational methods of command, which might be helpful in the decision making process on the battlefield on tactical and operational levels. The methods allow activating subordinates as well as delegating authority. They also carry qualities and functions that allow taking full advantage of the knowledge and wisdom of subordinates. They may also become useful in the implementation of the training process and current activities.
\end{abstract}

Keywords: Command methods, tactical level, operational level, command through motivation, command through personal contact, command through delegating authority, command through controlling, results.

\section{Introduction}

The article presents inspirational methods of command, which might be helpful in the decision making process on the battlefield on tactical and operational levels. The methods allow activating subordinates as well as delegating authority. They also carry qualities and functions that allow taking full advantage of the knowledge and wisdom of subordinates. They may also become useful in the implementation of the training process and current activities.

When making an in-depth analysis of the existing methods of command (through objectives, tasks and instructions) often referred to and commented on in military publications, one may come to a conclusion that they do not utterly exploit the full organizational capabilities of commanders and their staffs. The author proposes, therefore, especially in the period of training and current activities, commanding through motivation, personal contact, delegating authority and responsibilities and controlling. Obviously, this does not exclude any leadership restrictions through objectives, tasks or instructions. He also believes also that all exercises and training, with or without the participation of military forces, should be conducted in conditions similar to a real battlefield, definitely with methods which will be exploited in wartime operations.

The unconventional methods of leadership, which will facilitate the fulfilment of the command role on modern battlefield, are as follows:

\footnotetext{
${ }^{*}$ Corresponding author

Email address: a.rurak@wsosp.pl (Adam Rurak)
}

- Command through motivation;

- Command through personal contact;

- Command through delegating authority;

- Command through controlling (results).

These methods can be defined with characteristic features specified in Table 1.

When proposing a new set of methods of command in the armed forces, one needs to understand and recognise the demands in the context of the whole complexity of the problem and the core of the command process [1, p. 33]. It is also necessary to observe the fundamental principle that in command practice there are different parallel or alternate methods of command [2, p. 262]. This has been done intuitively since there appeared specialized armed forces which serve achieving economic goals in the first place, and then further political goals. The winning chieftains were glorified by their tribesmen and rewarded with sometimes stunning kindness of rulers whom they served. The chieftains returning from battlefields where their troops had suffered defeat, were subject to infamy or became beheaded. The problem is vividly presented in the trilogy of Henryk Sienkiewicz who describes a Turkish magnate hand over a rope to the chieftain who was responsible for the defeat of the forces he was in charge of. The loser had no alternative. He made use of the rope since any doubts would make him lose his life in disgrace and torment. Does the above-mentioned practice illustrate a drastic example of command through motivation? The question is rhetorical. While suggesting a method of command through 
Safety \& Defense 4 (1) (2018) 1-4

Table 1: Main features of activating methods of command in the Air Force. Own research

\begin{tabular}{|c|c|c|c|c|c|c|}
\hline $\begin{array}{l}\text { Methods } \\
\text { of command }\end{array}$ & $\begin{array}{l}\text { Unlimited devotion of } \\
\text { soldiers executing tasks }\end{array}$ & $\begin{array}{c}\text { Increase } \\
\text { in initiative }\end{array}$ & $\begin{array}{c}\text { Exerting } \\
\text { strong pressure }\end{array}$ & $\begin{array}{l}\text { Possibility of correction of } \\
\text { actions of subordinates }\end{array}$ & $\begin{array}{l}\text { Developing independence } \\
\text { and efficiency }\end{array}$ & $\begin{array}{l}\text { Continuity } \\
\text { of command }\end{array}$ \\
\hline $\begin{array}{l}\text { Command through } \\
\text { motivation }\end{array}$ & $x$ & $x$ & & & $x$ & $x$ \\
\hline $\begin{array}{l}\text { Command through } \\
\text { personal contact }\end{array}$ & $x$ & & $x$ & $x$ & & $x$ \\
\hline $\begin{array}{l}\text { Command through } \\
\text { delegating authority }\end{array}$ & & $x$ & & & $x$ & $x$ \\
\hline $\begin{array}{l}\text { Command through } \\
\text { controlling (findings) }\end{array}$ & & & $x$ & $x$ & & \\
\hline
\end{tabular}

motivation, it is necessary to bear in mind not only its historical attributes, although they perfectly illustrate the method of command through motivation in contemporary conditions. The serious historical study and accounts of living witnesses of World War Two provide a great deal of reliable evidence, proving the prominent role of command through motivation and sacrifice on the battlefield in World War Two.

\section{Command Through Motivation}

The means by which command through motivations is realized is included in the sphere of variable factors. In a highly civilized society, free from religious and nationalist fanaticism, there is little chance to rekindle primitive means of raising motivation to execute fanatical tasks on the battlefield. There is a sound basis to a statement that in present-day Japan it would become impossible to reconstruct "kamikazestyle" as was the case by the end of World War Two. However, in numerous suicide bombings which are linked with terrorist attacks, often inspired by enemies of democracy, perpetrators only accept hatred and religious fanaticism as motivation. Suicide terror shows how effective human motivation can be. The means of motivation may vary as they may be positive and negative, costly or economical. They should be available to commanders of troops and should facilitate the achievement of the intended goals in the psychological and practical sphere. Usually, forces or assets committed in combat or during the whole war are not limitless. Therefore, commanders should stand out with their ability to use positive measures which they have at their disposal as well as the ability to use external factors, which may be less effective than the "regular instruments". An example which illustrates the essence of the problem on a macro scale was the attitude of Nazi Germany towards Red Army prisoners of war (in the area of Kiev, Bialystok), whose thousands surrendered to Nazis pressing eastwards. Single prisoners who managed to free themselves from death brought news to the East of merciless extermination or death starvation of captured Soviet prisoners of war, which accurately reflected the reality. Such a situation resulted in the desperate resistance of the Red Army soldiers, intensified by the cruel treatment of those Soviet soldiers who had been captured by the Germans. Their families were also treated in a brutal manner.
Thus, it may be concluded that the Red Army soldiers had two cruel enemies - Nazi troops and their own firing squads. Red Army soldiers were confronted with a no-choice situation. The only reasonable way out was to either become victorious in the fight or die. The mentioned facts illustrate the measures (instruments) of motivation, which were negative, cruel and widespread. Fortunately, the vast majority of world armies are in possession of large arsenals of positive measures of motivation (well-known), as well as measures of persuasion and methods of negative motivation (military police, police chiefs, public prosecutors, courts and firing squads).

The main feature of the motivation method of command is obtaining a maximum number of persons under command who will become involved in the task execution. The primary incentive measures are undoubtedly positive instruments, such as:

- winning hearts and minds of the commanded soldiers;

- inspiring subordinates to boundless sacrifice in the fulfilment of the assigned combat objectives (war).

The measures of negative motivation are regarded as the so-called necessary evil with reference not only to the resistant ones (insensitive to stimuli of a higher order). The very existence of negative measures is the contrast, in a way the other pole, which expands the desired effects of positive measures [3, p. 8].

\section{Command Through Personal Contact}

The command method through personal contact was also used in the past, but more intuitively, in response to the emerging agreements, and not as fully intentional activities of those in command. Apart from unquestionable prerogatives, this method raises a number of threats. The positive effects are possible to achieve provided the leader and those under command represent a high intellectual level and are deprived of typical psychological shortcomings. It is essential to remember about the general reluctance of those under command towards incessant monitoring by superiors. This is the consequence of the risk of being deprived of prerogatives of subordinates and continuous domination of the superior, which often leads to undermined authority of the lower-rank 
commander in the eyes of their subordinates. The leader, through personal contact, will certainly not conceal minor or major failures. The meaning of the above-mentioned threats and fears can be illustrated on the example of a relationship between commanders of troops and the commander of a tactical unit. Unit commanders, dispersed in separate garrisons, feel more valued compared to subordinates in a common garrison, where daily contact with the superior is inevitable. The objective threat, leading to the elimination of the initiative of subordinates is the continuous personal contact of the commander with those in charge. At the level of the platoon, company, battalion, and especially a squadron, the method of command through personal contact has no alternative. At higher levels of command its use cannot take the form of pathology. The superior must reduce the interference in the work of subordinates so as not to disturb them or restrict their respective commanding prerogatives. The greatest benefit of this method of leadership is the elimination of intermediaries between the commander and the commanded one/s, namely people (staffs), technical means of communication and documents.

The positive qualities of this method of command include:

1. in-depth knowledge of the subordinate's position and their ability to perform tasks (training);

2. immediate passing of orders, messages (information) in the superior - subordinate relationship, and vice versa;

3. possibility of concealed command by eliminating outside parties and possible leaking of information to the enemy;

4. direct supervision of task execution and ability to eliminate errors in their performance by subordinates, (however, with a simultaneous natural threat from harmful interference with the work of subordinates) $;^{1}$

5. ability to support subordinates in the execution of tasks on the basis of current knowledge of the needs of the subordinate [4, p. 23].

Using the method of command through personal contact and all the other recommended methods cannot violate the commonly accepted rules of command. Especially, the method of personal contacts poses a threat in the principle of single person leadership. The commander, following the traditions of the rules, should not ignore their superior or attempt at interfering into the work of the subordinates. Only the social sphere does not exclude such a possibility. Under no circumstances may the official way be violated, and it concerns the relationships of the superior-subordinate and the subordinate - superior.

\section{Command Through Delegation of Authority}

A method of command through delegation of authority involves optimal assigning of competences and command re-

${ }^{1}$ The threat in question is not an immanent feature of this method of command, but possibly of the commander's shortcomings, insufficient intellect or fundamental experience. sponsibilities to subordinates, in a given situation. The person using this method should assign to subordinates not only command tasks, which he is incapable of executing on their own, but intentionally deal with only main problems and provide as much time as possible to settle them [5, p. 20]. This method develops an initiative of subordinates, ensures continuity of command, develops autonomy of subordinates as well as ensuring their effective actions even in conditions of a temporary communications failure with the superior. The author comes to a conclusion that a higher level of command entails a broader spectrum of delegated competences and tasks to grapple. So far, the delegation of powers in the armed forces has been implemented in a rather narrow way. Such a phenomenon is a derivative of transformations occurring in the economic sphere of the state. In the recent past, not only general armament problems but also minor problems of home security were settled at the level of the Ministry of National Defence and the General Staff [6, p. 227]. Troops, tactical units and military institutions obtained standard material allowances, sometimes unnecessary due to the conducted stock-taking, while other goods were lacking.

It is necessary for the delegation method to be accompanied with obeying the following principles:

1. Leaving, in the hands of the commanding (delegating) officer the authority to avoid loss of command; ${ }^{2}$

2. The person who delegates authority should take into account individual qualities of the subordinates who receive the authority (intellect, intelligence, education and experience, psychological qualities, particularly the sense of responsibility, sound judgement and talents);

3. The delegated powers may be granted for a specified period of time or permanently;

4. The duties and responsibilities delegated to subordinates should be formulated in a clear manner for all concerned ones; the Air Force is an extremely costly kind of military forces, and the weight of operation of even small tactical groups of aircraft may assume strategic significance;

5. The powers delegated to subordinates should be commensurate with the possessed information by them of the objectives and tasks of training, or a tactical and operational situation during the war. The accuracy of the decisions made depends on the overall skill of the commander (their staff) and knowledge of their position, enemy position, and other determinants influencing the effectiveness of own force and assets.

Delegation of authority is not an expression of goodwill or grace of the superior, but it is set to ensure good leadership. The sight of a commander being overworked in a vicious circle of duties that he is incapable of handling is not only pa-

\footnotetext{
${ }^{2}$ By "loss of command" the author understands the state in which the commanded troops (sub-unit, unit, tactical formation and higher) lose combat readiness or ability to fulfil combat tasks resulting from their destiny as well as the capabilities of men and equipment.
} 
thetic, but also likely to compromise the duties. A commander who is in charge of tens, hundreds, or thousands of soldiers, and who is unable to use people's talents in their own command gives evidence of incomplete suitability to execute their role.

\section{Command Through Control}

The command method through controlling is the most recent idea. The armed forces of all the armies across the world have inspired scientists dealing with management to formulate the regularities in management of economy and other companies based on the military. The quality of the armed forces is certain conservatism. This assessment is of a general nature and applies to all the armies worldwide. When we recall this well-known regularity, it can be said that controlling, as a new idea, may not always be welcome. This is due to the fact that the controlling system in the Polish Armed Forces is based on evaluation of the smallest constituent elements, organizational structures, subunits, units, tactical formations and other institutions, and the overall rating is the average resultant from scores of completely different components. For example, the proverbial painting of pavement curbs white and the technical efficiency of some equipment are, after all, completely different components of the overall assessment.

On the other hand, commanding through controlling denotes setting primary (ultimate) objectives of training or combat and, on this basis, accounts for performance [7, p. 14]. An example of general objectives for combat training might be the result of air shooting or bombardment of ground (naval) targets. Such an understanding of the method of command (giving tasks and accounting for their execution) means a complete shift in the philosophy of shaping training and combat activities of the military. During the application of controlling, the superior is not interested in the number of academic hours of training conducted in various training groups or even in the number of pilotage flights made by individual crews. The ability to perform tasks by the entire squadron, base, wing is enforced since it is the essence of the efficiency and combat readiness of the Air Force.

One should be aware, however, that the introduction of this method of command is still not possible these days. The current regulations, instructions, educational programmes for soldiers and numerous collections of orders and directives describe in detail and explicitly training activities of the armed forces. Thus, the introduction of controlling, as a method of command, is out of the question, since it would constitute a denial of the orders contained in the above-mentioned documents. Hopefully, this method of command by controlling will be implemented in the foreseeable future and its exploitation will yield positive effects, eliminating notional activities.

As it is clear from the content of Table 1, developed mainly on the basis of experts' opinions, the most positive characteristics, regarded as the main ones, are the command methods through motivation and personal contact. In the third place there is the method of command through delegation of authority, and lastly through controlling.

The author hopes that the inspirational methods of command will enrich the arsenal of organisational capabilities of commanders and their staffs.

\section{Conclusions}

The above suggestions are just the beginning of the discussion and deliberations. They only show how much there still needs to be done in this field and how important the role of man, his intellect, good preparation is, especially in terms of command, management and control of larger or smaller teams [8, p. 41] on the future battlefield.

A good commander must possess leadership qualities. The essence of this type of leadership should be cooperation, especially with subordinates, and joint thinking over the concept of action in order to achieve the objective. A modern commander must be aware of double responsibility, both individually and in a team.

\section{References}

[1] E. Zabłocki, Siły powietrzne w sojuszniczym systemie obronnym., Dęblin: Wydawnictwo WSOSP (2009).

[2] Z. Pawlak, Zarządzanie zasobami ludzkimi., Warszawa: Wydawnictwo Poltex. (2011).

[3] R. Rigby, Wielcy świata biznesu., Warszawa: Oficyna Wolters Kluwer Business (2011).

[4] R. Wegman et al., Zarządzanie zespołami liderów., Warszawa Oficyna Wolters Kluwer Business (2012).

[5] M. A. Leśniewski, Kompendium wiedzy z zarządzania organizacjami., Kielce: Wydawnictwo Akademii Świętokrzyskiej. (2007).

[6] Z. Trejnis, Obronność państwa. Strategie oraz systemy bezpieczeństwa i obronności., Toruń: Wydawnictwo Adam Marszałek. (2016).

[7] J. Bieniek et al., Zarządzanie, planowanie i controlling, Warszawa (1998).

[8] A. Kwasiborska, Bezpieczeństwo transportu lotniczego., Warszawa: Oficyna Wydawnicza ASPRA-JR (2016).

[9] J. Cendrowski, S. Swebocki, Psychologia walki i dowodzenia., Warszawa: MON (1973).

[10] S. Dworecki, T. Kęsoń, Konflikty zbrojne w europie i na bliskim wschodzie., Warszawa: MON (1996).

[11] S. Kowalski, Przełożony i podwładny. (1967).

[12] A. G. Macdonell, Napoleon i jego marszałkowie., Warszawa: PWN (1992).

[13] T. Szapiro, Co decyduje o decyzji., Warszawa: PWN. (1993).

[14] M. Łaszczyk, Nowe formy rozkazodawstwa na szczeblu operacyjnymi taktycznym., Warszawa: AON (1994). 